\title{
The use of date waste for lactic acid production by a fed-batch culture using Lactobacillus casei subsp. rhamnosus
}

\author{
Aicha Nancib ${ }^{1}$, Nabil Nancib ${ }^{1}$, Abdelhafid Boubendir ${ }^{1}$, Joseph Boudrant ${ }^{2}$ \\ ${ }^{1}$ Laboratory of Applied Microbiology, Ferhat Abbas University, Setif, Algeria. \\ ${ }^{2}$ Laboratory Reactions and Chemical Engineering, University of Lorraine, Vandoeuvre Cedex, France.
}

Submitted: October 7, 2013; Approved: October 9, 2014.

\begin{abstract}
The production of lactic acid from date juice by Lactobacillus casei subsp. rhamnosus in batch and fed-batch cultures has been investigated. The fed-batch culture system gave better results for lactic acid production and volumetric productivity. The aim of this work is to determine the effects of the feeding rate and the concentration of the feeding medium containing date juice glucose on the cell growth, the consumption of glucose and the lactic acid production by Lactobacillus casei subsp. rhamnosus in fed-batch cultures. For this study, two concentrations of the feeding medium (62 and $100 \mathrm{~g} / \mathrm{L}$ of date juice glucose) were tested at different feeding rates $(18,22,33,75$ and $150 \mathrm{~mL} / \mathrm{h})$. The highest volumetric productivity $(1.3 \mathrm{~g} / \mathrm{L} . \mathrm{h})$ and lactic acid yield $(1.7 \mathrm{~g} / \mathrm{g})$ were obtained at a feeding rate of $33 \mathrm{~mL} / \mathrm{h}$ and a date juice glucose concentration of $62 \mathrm{~g} / \mathrm{L}$ in the feeding medium. As a result, most of the date juice glucose was completely utilised (residual glucose $1 \mathrm{~g} / \mathrm{L}$ ), and a maximum lactic acid production level $(89.2 \mathrm{~g} / \mathrm{L})$ was obtained.
\end{abstract}

Key words: fed-batch culture, lactic acid, Lactobacillus casei subsp. rhamnosus, date juice.

\section{Introduction}

Lactic acid and its derivatives are widely used in food, pharmaceutical, leather, and textile industries. Furthermore, because lactic acid has excellent reactivity due to the presence of carboxylic acid and hydroxyl groups, it can undergo a variety of chemical conversions into potentially useful chemicals. Lactic acid fermentation processes have currently received much more attention because of the increasing demand for new biomaterials such as biodegradable and biocompatible polylactic products (Gao et al., 2011).

The efficiency and economics of the ultimate lactic acid fermentation is still a problem from many points of view, and media composition plays a vital role in the improvement of such a process. Currently, research efforts are focused on discovering new and effective nutritional sources and utilising new progressive fermentation techniques, enabling the achievement of both high substrate conversion and high productivity. Lactic acid production has been studied with various raw materials, such as barley, wheat and corn (Oh et al., 2005). As mentioned earlier by
Nancib et al. (1997), Algeria produces different varieties of dates, and the annual production in 2008 was 500,000 tons (El-Juhany, 2010). However, approximately $20 \%$ of the production may be lost due to over-ripening, improper handling, processing, and marketing. To consider this problem, the utilisation of poor-quality dates and date by-products have been previously investigated in the food product manufacturing of items such as bakery products, ice-cream, caramel products, ethanol, vinegar (Mehaia, 1991), oxytetracycline (Abou-Zeid et al., 1993), single-cell protein (Nancib et al., 1997), lactic acid (Nancib et al., 2009), glutamic acid (Tavakkoli et al., 2009), carotenoids (LunaFlores et al., 2010) and curdlan gum (Ben Salah et al., 2011). In fact, dates contain large amounts of glucose at levels of $73-83 \%$ (dry basis), and they also contain proteins, lipids, mineral elements and some vitamins (Abou-Zeid et al., 1991), making date extracts particularly suitable as fermentation substrates.

Batch fermentation has been the method used industrially for lactic acid production. However, the major disadvantage of batch fermentation is that both the lactic acid concentration and productivity decrease due to inhibition 
by high substrate concentration, which is a general characteristic of batch fermentation (Hujanen et al., 2001). A fed-batch culture is a batch culture continuously or sequentially fed with substrate possibly coupled with removal of the fermentation broth. This type of process is generally more efficient than batch and continuous processes, and it is especially beneficial when changes to the nutrient concentration affect the productivity and biomass of the desired product (Lee et al., 1999). However, until now there have been only a few systematic reports on fed-batch fermentation for the production of lactic acid by bacteria (Roukas and Kotzekidou, 1998; Bai et al., 2003; Liu et al., 2005; Ding and Tan 2006; Yen and Kang, 2010; Zhang et al., 2011).

In the present work, the effects of combining both the feeding rate and the date juice glucose concentration of the feeding medium during the fed-batch fermentation by $L$. casei subsp. rhamnosus were studied for maximum lactic acid volumetric productivity and concentration, and low residual glucose concentration.

\section{Materials and Methods}

\section{Microorganism}

L. casei subsp. rhamnosus NRRL-B445, a homofermentative lactic acid producer, was used. Stock cultures (1 mL) were stored at $-20{ }^{\circ} \mathrm{C}$ in Lactobacilli MRS medium with $25 \%(\mathrm{v} / \mathrm{v})$ glycerol.

\section{Date juice extract}

The used substrate was obtained from date waste. The date waste or sorting date discards are a part of the palm tree fruit and are not suitable for human consumption. The date waste and discards are generally used for feedstock. The method used for sugar extraction from these dates was adapted from Nancib et al. (1999). The dates were thoroughly cleaned manually to remove dust and foreign materials. The seeds were separated by manual splitting. Tap water was added at a ratio of two parts of water to one part of dates (by weight). The mixture was heated at $80{ }^{\circ} \mathrm{C}$ for $2 \mathrm{~h}$ with continuous stirring. The mixture was centrifuged at $20,000 \times \mathrm{g}$ for $10 \mathrm{~min}$. to remove the cellulosic debris while the supernatant was used essentially as a carbon source in the fermentation medium. Immediately prior to each experiment, an appropriate quantity of date juice was diluted to the desired concentration of glucose. The glucose content of the collected supernatant was determined.

\section{Production medium}

The medium consisted of date juice glucose prepared at a concentration of $45 \mathrm{~g} / \mathrm{L}$. The medium was sterilised at $121^{\circ} \mathrm{C}$ for $20 \mathrm{~min}$. After cooling, the date juice was supplemented with yeast extract, $10 \mathrm{~g} / \mathrm{L} ; \mathrm{MgSO}_{4} \cdot 7 \mathrm{H}_{2} \mathrm{O}$ (Merck, Darmstadt, Germany), $0.5 \mathrm{~g} / \mathrm{L} ; \mathrm{MnSO}_{4} \cdot \mathrm{H}_{2} \mathrm{O}$ (Merck, Darmstadt, Germany), $0.03 \mathrm{~g} / \mathrm{L} ; \mathrm{KH}_{2} \mathrm{PO}_{4}$ (Merck,
Darmstadt, Germany), 3 g/L; $\mathrm{K}_{2} \mathrm{HPO}_{4}$ (Merck, Darmstadt, Germany), $3 \mathrm{~g} / \mathrm{L} ; \mathrm{CH}_{3} \mathrm{COONa} .3 \mathrm{H}_{2} \mathrm{O}$ (Biokar, Beauvais, France), $2 \mathrm{~g} / \mathrm{L}$ and Tween 80 (Sigma-Aldrich, Deisenhofen, Germany), $1 \mathrm{~mL} / \mathrm{L}$ (the solutions of nutrients were sterilised separately).

\section{Inoculum preparation}

The inoculum was prepared by transferring glycerol stock culture $(1 \mathrm{~mL})$ to an Erlenmeyer flask containing $100 \mathrm{~mL}$ of liquid MRS medium for pre-culture. The flask was subsequently incubated at $38{ }^{\circ} \mathrm{C}$ for $12 \mathrm{~h}$, the time needed for the microorganism to reach the exponential growth phase. Then, a fermentor containing the production medium was inoculated with a portion of the pre-culture. A $10 \%$ inoculum grown in the MRS medium was used in all fermentations.

\section{Fermentation conditions}

Batch cultivations were performed in a 21 stirred tank fermentor (Biolafitte, St-Germain-en-Laye, France) with a working volume of $1 \mathrm{~L}$. The $\mathrm{pH}$ value of the cultures was automatically maintained at 6.0 by adding a $5 \mathrm{~N} \mathrm{NH}_{4} \mathrm{OH}$ solution, and the temperature was maintained at $38^{\circ} \mathrm{C}$ with an agitation speed of $200 \mathrm{rpm}$.

Fed-batch cultivations were carried out in a $10 \mathrm{~L}$ stirred tank fermentor (LKB, Bromma, Sweden) and the initial working volume was set at $1 \mathrm{~L}$. After inoculation, batch fermentation was performed for $24 \mathrm{~h}$. Then, the fed-batch step was initiated with a supply of feed medium. The feeding medium, which contained date juice glucose (62 or $100 \mathrm{~g} / \mathrm{L}$ ), was continuously added into the fermentor with a peristaltic pump at different feeding rates $(18,22,33$, 75 and $150 \mathrm{~mL} / \mathrm{h}$ ). All experiments were performed in duplicate.

\section{Analytical methods}

The cell concentration was estimated by measuring the optical density at $620 \mathrm{~nm}$ and correlating that measurement to dry cell weights: one OD unit $=0.5 \mathrm{~g}$ cell mass $/ \mathrm{L}$. The glucose and lactic acid concentrations were determined by high-pressure liquid chromatography (HPLC) equipped with an RI, UV detector (Waters, USA). The column used was a Polypore $\mathrm{H}(250 \times 7 \mathrm{~mm})$ (Brownlee labs, USA) operated at $65{ }^{\circ} \mathrm{C}$ using $0.04 \mathrm{~N} \mathrm{H}_{2} \mathrm{SO}_{4}$ as the eluent at a flow rate of $0.9 \mathrm{~mL} / \mathrm{min}$.

\section{Results and Discussion}

\section{Batch culture}

The cultivation of $L$. casei subsp. rhamnosus was performed to investigate the kinetics of cell growth, glucose consumption, and lactic acid production in batch culture. As shown in Figure 1, the cells grew exponentially and reached their maximal density of 20 after 15 hours. During the cell growth phase, the glucose concentration in culture 


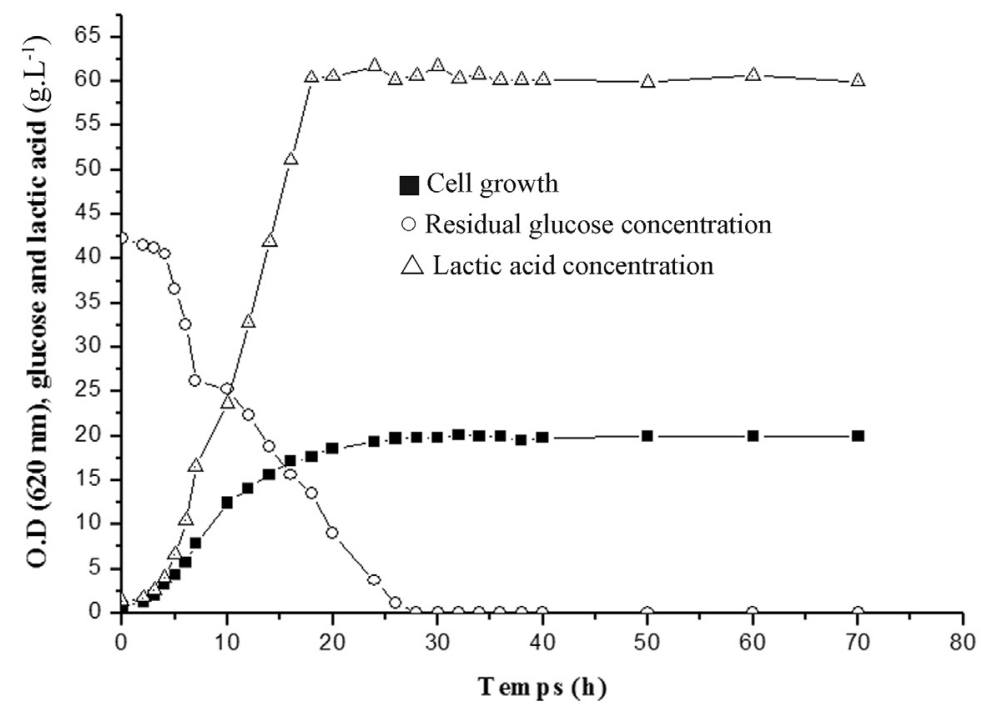

Figure 1 - Lactic acid production from date juice by L. casei subsp. rhamnosus in batch cultivation.

decreased gradually. However, during the cell growth phase, the lactic acid accumulated in the culture reached its maximal concentration of $60 \mathrm{~g} / \mathrm{L}$ after 24 hours. After that time, the lactic acid concentration remained almost the same for the rest of the cultivation time.

\section{Fed-batch culture}

Fed-batch cultivations were designed to improve lactic acid production through the elimination of glucose limitations during the culture process. Different assays were performed to determine the effect of the feeding rate on cell growth, glucose consumption and lactic acid production. For these experiments, the initial batch phase was per- formed using the production medium (see Materials and methods) and lasted $24 \mathrm{~h}$. For the fed phases, the date juice solution used for feeding had a glucose concentration of $62 \mathrm{~g} / \mathrm{L}$ and the feeding rates were 33,75 and $150 \mathrm{~mL} / \mathrm{h}$.

The obtained results are shown in Figure 2. These results highlight (Figure 2a) that at a rather high feeding rate $(150 \mathrm{~mL} / \mathrm{h})$, the glucose is not completely consumed; its concentration stabilises at $16 \mathrm{~g} / \mathrm{L}$. The lactic acid productivity also appears low $(0.8 \mathrm{~g} / \mathrm{L} . \mathrm{h})$ (Table 1$)$. In fact, this feeding strategy is subject to the substrate inhibition effect because the level of glucose concentration in the medium remained relatively high during the fermentation process. This was because the addition of glucose was not at an ap-

Table 1 - Effects of the feeding rate and the concentration of the feeding date juice glucose on the cell growth and lactic acid production.

\begin{tabular}{|c|c|c|c|c|c|c|}
\hline $\begin{array}{l}\text { Feeding rate } \\
(\mathrm{mL} / \mathrm{h})\end{array}$ & $\begin{array}{l}\text { Feeding glucose } \\
\qquad(\mathrm{g} / \mathrm{L})\end{array}$ & $\begin{array}{c}\text { Biomass } \\
\text { concentration }(g / L)\end{array}$ & $\begin{array}{c}\text { Final lactic } \\
\text { concentration }(\mathrm{g} / \mathrm{L})\end{array}$ & $\begin{array}{l}\text { Lactic acid productivity } \\
\qquad(\mathrm{g} / \mathrm{L} \cdot \mathrm{h})^{\mathrm{a}}\end{array}$ & $\begin{array}{l}\text { Lactic acid yield } \\
\qquad(\mathrm{g} / \mathrm{g})^{\mathrm{b}}\end{array}$ & $\begin{array}{l}\text { Specific growth } \\
\text { rate }(\mu)\left(\mathrm{h}^{-1}\right)^{\mathrm{c}}\end{array}$ \\
\hline 150 & 62 & 10.4 & 56.9 & 0.80 & 1.4 & 0.100 \\
\hline 75 & 62 & 11.1 & 75.2 & 1.00 & 1.5 & 0.090 \\
\hline 33 & 62 & 11.8 & 89.2 & 1.30 & 1.7 & 0.080 \\
\hline 33 & $62^{*}$ & 8.3 & 57.8 & 0.80 & 1.3 & 0.076 \\
\hline 33 & 100 & 9.7 & 79.4 & 1.13 & 1.4 & 0.078 \\
\hline 22 & 100 & 10.4 & 80.4 & 1.15 & 1.4 & 0.076 \\
\hline 18 & 100 & 10.3 & 84.9 & 1.21 & 1.5 & 0.075 \\
\hline
\end{tabular}

*Supplements are the same components as the production medium.

${ }^{a}$ The productivity was calculated using the equation: $\delta=\frac{P_{t} V_{t}-P V_{0}}{\left(t_{t}-t_{0}\right) V_{t}}$.

${ }^{\mathrm{b}}$ The yield was calculated using the equation: $Y_{P / S}=\frac{P_{t} V_{t}-P_{0} V_{0}}{S_{0} V_{0}-S_{t} V_{t}+\left(V_{t}-V_{0}\right) S_{a}}$.

${ }^{\mathrm{c}}$ The specific growth rate was calculated using the equation: $\mu=\left[\ln \frac{V X}{V_{0} X_{0}}\right] \times \frac{1}{t}$.

$P_{t}$ : Final lactic acid $(\mathrm{g} / \mathrm{L}) . V_{t}$ : Final volume of the fermentor $(\mathrm{L})$. $V_{0}$ : Initial volume of the fermentor $(\mathrm{L}) . P_{0}$ : Initial lactic acid $(\mathrm{g} / \mathrm{L})$. $S_{a}:$ Glucose concentration of the feeding date juice solution $(\mathrm{g} / \mathrm{L})$. $S_{t}$ : Residual glucose concentration $(\mathrm{g} / \mathrm{L}) . X_{0}$ : Initial biomass concentration $(\mathrm{g} / \mathrm{L})$. $X:$ Final biomass $(\mathrm{g} / \mathrm{L})$. 

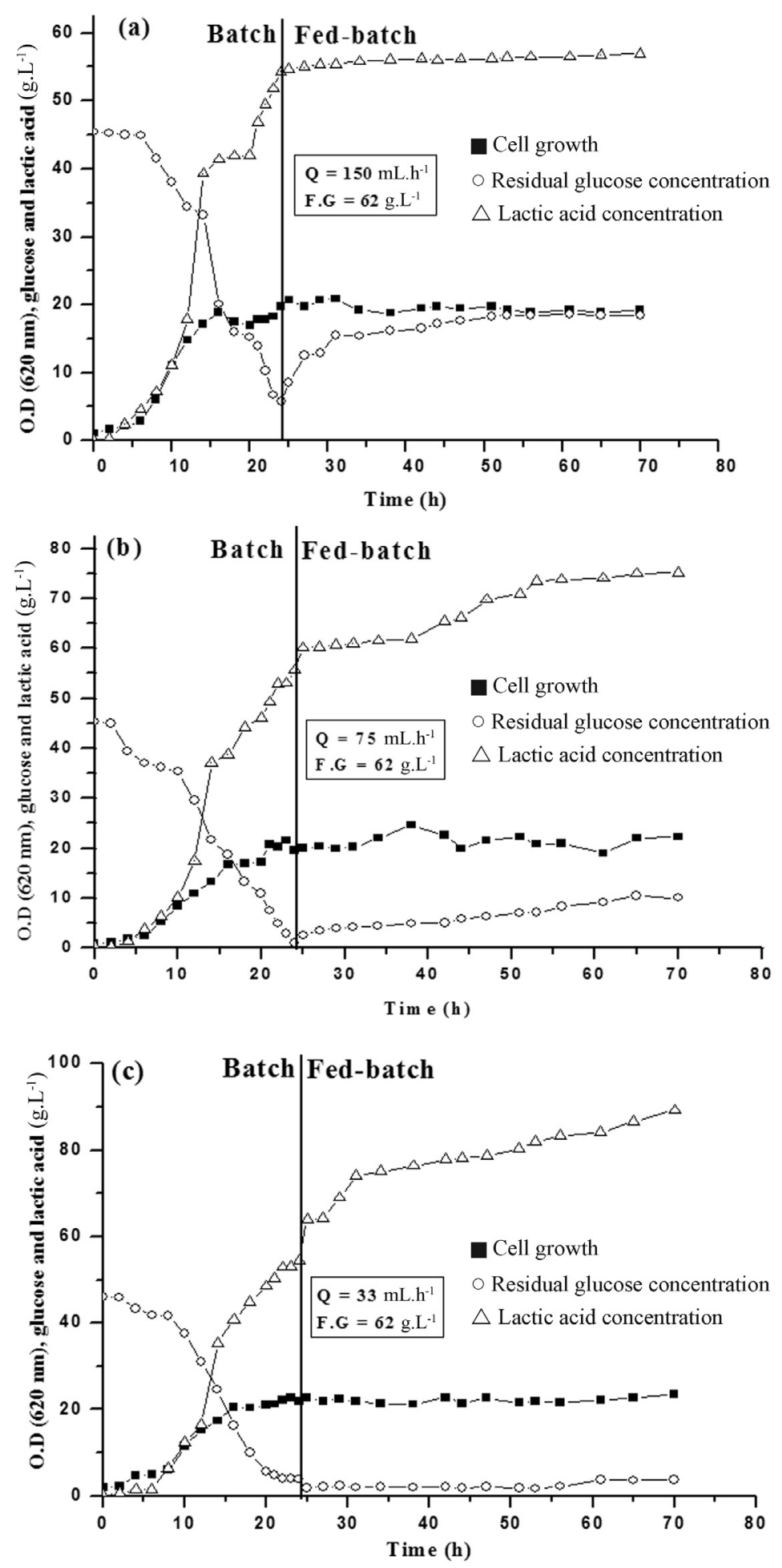

Figure 2 - (a, b, c) - Effect of the feed rate on cell growth, residual glucose and lactic acid production in a fed-batch culture using date juice glucose as the feeding medium $(62 \mathrm{~g} / \mathrm{L})$. Indices: Q: Feeding rate; F.G: Glucose concentration of the feeding solution.

propriate value, and the glucose utilisation rate was not at its maximum. However, in all fed-batch processes, the substrate concentration in the fermentation broth remains unstable, thereby generating more stress on the producing strain. By the application of a low level feed rate, the problem of a disrupted low volumetric productivity could be avoided, and the lactic acid concentration likely could be enhanced. 
Therefore, in the second experiment, the feed rate was reduced to half of this value $(75 \mathrm{~mL} / \mathrm{h})$. Compared to the precedent rate of feeding, a low feed rate fed-batch yielded a better result. As shown in Figure $2 b$, the lactic acid production is then more important $(75 \mathrm{~g} / \mathrm{L})$, and an improvement in the glucose consumption (residual glucose, $10 \mathrm{~g} / \mathrm{L}$ ) is observed. The lactic acid productivity level is also higher than the level observed in the previous experiment (1 g/L.h) (Table 1). In a third experiment, the feeding rate was fixed at a lower value: $33 \mathrm{~mL} / \mathrm{h}$. The residual glucose decreased gradually (until $2 \mathrm{~g} / \mathrm{L}$ ), even after a continuous addition of glucose date juice solution (Figure 2c). Notably, the lactic acid also reached a maximum level simultaneously as the glucose depleted. The final concentration of lactic acid was then much higher $(89.2 \mathrm{~g} / \mathrm{L})$, whereas the residual glucose level was lower $(2 \mathrm{~g} / \mathrm{L}$, Figure $2 \mathrm{c})$ and the resulting lactic acid productivity was higher (1.3 g/L.h) (Table 1$)$. Thus, according to these results, this third feeding rate, which was the lowest, seems to be more efficient. Indeed, the addition of a concentrated substrate solution at a low rate was accomplished while maintaining a substrate concentration in the reactor below the inhibition level (Qureshi and Blaschek, 2001). Such conditions allow us to determine the appropriate amount of the carbon source to add to the medium such that the cells are able to efficiently utilise the substrate. Moreover, substrate inhibition is also minimised as the glucose concentration remains lower than $2 \mathrm{~g} / \mathrm{L}$ throughout the process. However, the feeding rate had no obvious influence on the biomass accumulation (Figure 2), which corroborates the observation of Bai et al. (2003). This is most likely due to the inhibition of the cells by lactic acid, especially at high concentrations. The maximum observed specific growth rate $(\mu)$ was $0.1 \mathrm{~h}^{-1}$. Globally, the specific growth rate decreased with the increase in lactate concentration. At $84.9 \mathrm{~g} / \mathrm{L}$ lactic acid concentration, the specific growth rate reduced to approximately $22 \%$ (Table 1). Many reports have described the response mechanisms to environmental changes in Lactobacillus species. It is known that the exposure of microbial cells to stressful conditions during fermentation involves a broad transcriptional response with many induced or repressed genes (Serrazanetti et al., 2011). However, a significant number of works have already been shown to exhibit the inhibitory effects of lactic acid on the Lactobacillus cells (Wee et al., 2006). One more problem associated with lactic acid production via fermentation is the end product inhibition. Increased levels of undissociated lactic acid have been shown to inhibit the fermentation of several lactic acid producers. Therefore, trapping the undissociated lactic acid as lactate salt during fermentation would partially overcome such inhibition and improve fermentation efficacy (AbdelRahman et al., 2013).

\section{Influence of a supplementation of the feeding medium}

To determine if supplementation of the feeding medium in nitrogen and salts is efficient or necessary to improve the performances of fermentation, the feeding medium of the date juice at $62 \mathrm{~g} / \mathrm{L}$ glucose concentration was supplemented with the same components present in the production medium (see Materials and methods). For this experiment, the feeding rate was fixed at the lowest value, $33 \mathrm{~mL} / \mathrm{h}$, because at this value, the lactic acid productivity is the highest, and it is proposed that this is level where the cells have the largest nutritional requirement.

The obtained results, indicated in Figure $3 \mathrm{a}$, show no improvement and is even less efficient. The residual glucose concentration $(10 \mathrm{~g} / \mathrm{L})$ is higher (against $2 \mathrm{~g} / \mathrm{L}$ obtained without supplementation, Figure 2c), lactic acid production $(57.8 \mathrm{~g} / \mathrm{L})$ is lower than the previous experiment $(89.2 \mathrm{~g} / \mathrm{L})$ and the productivity $(0.8 \mathrm{~g} / \mathrm{L} . \mathrm{h})$ remains low (Table 1). Moreover, the results show that all the parameter values are lower than those obtained in the fed-batch cultivation using only date juice glucose $(62 \mathrm{~g} / \mathrm{L})$ as the feeding medium. Thus, complementation of the feeding medium with a nitrogen source (yeast extract) and salt does not improve the performances in fed-batch mode; it even decreases them. This result is most likely due to a higher osmotic pressure created by the presence of a high concentration of salts, proteins and sugars in the medium. In fact, lactic acid bacteria can be exposed to osmotic stress when appropriate quantities of salt or sugars are added to the product (Van de Guchte et al., 2002). Most of the Lactobacillus species used in lactic acid fermentation processes so far (i.e., L. casei and Lactobacillus rhamnosus) are not necessarily ideal candidates for fermentations in high salt conditions (Vasala et al., 2005). It was also shown that a high concentration of amino acids suppress the activity of the oligopeptide transport system, the system by which lactobacilli obtain the amino acids needed for protein synthesis (Kunji et al., 1996). Thus, we can conclude that fed-batch cultivation using date juice feeding without complementation is a suitable cultivation method for lactic acid production.

\section{Influence of the feeding medium concentration}

To evaluate the effect of the feeding medium concentration at a feeding rate of $33 \mathrm{~mL} / \mathrm{h}$, the date juice medium was then used at a glucose concentration of $100 \mathrm{~g} / \mathrm{L}$, and the results were compared with those indicated in Figure 2c, where the feeding rate was also at $33 \mathrm{~mL} / \mathrm{h}$, but the glucose concentration was $62 \mathrm{~g} / \mathrm{L}$. Under these conditions, the glucose is not well consumed, and the final concentration stabilises between 8 and $10 \mathrm{~g} / \mathrm{L}$ (Figure $3 \mathrm{~b}$ ).

The productivity was slightly lower (1.1 g/L.h) as well as the final concentration in lactic acid $(79.4 \mathrm{~g} / \mathrm{L})$, which was also lower than the levels obtained with the feeding medium at a glucose concentration of $62 \mathrm{~g} / \mathrm{L}$ (Ta- 

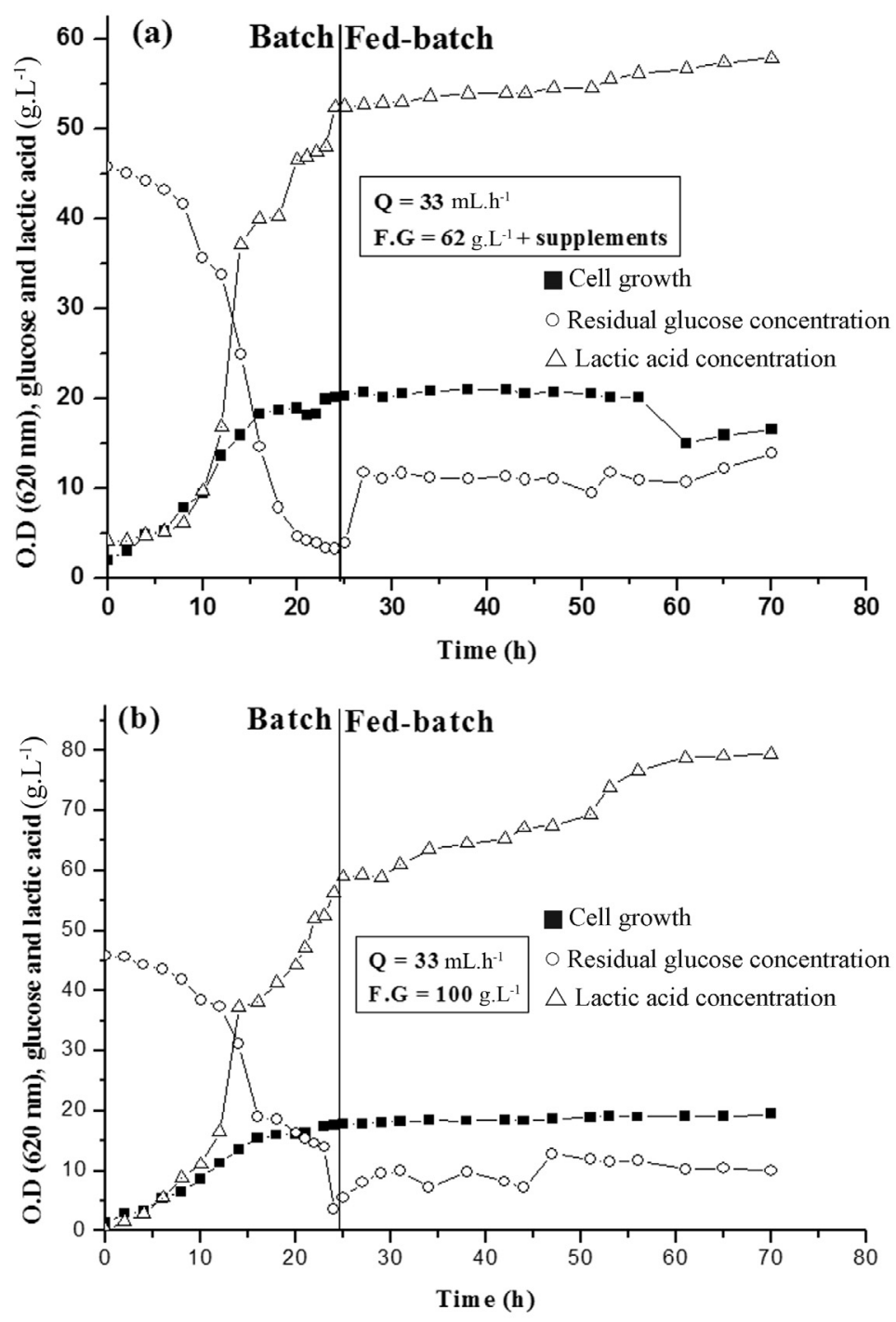

Figure 3 - $(\mathrm{a}, \mathrm{b})$ - Effect of the concentration of the feeding date juice glucose on cell growth, residual glucose and lactic acid production in fed-batch culture. Indices: Q: Feed rate; F.G: Glucose concentration of the feeding solution.

ble 1). The lactic acid concentration was then equal to $89.2 \mathrm{~g} / \mathrm{L}$. Thus, a combination of a glucose concentration of $100 \mathrm{~g} / \mathrm{L}$ and of a feeding rate of $33 \mathrm{~mL} / \mathrm{h}$ is not optimal, and interestingly, an increase in the date juice glucose concentration decreases the fermentation performance.

\section{Fed-batch assays at lower feeding rates}

Because the fermentation performances at $33 \mathrm{~mL} / \mathrm{h}$ were not the highest (see above), two additional fermentations were performed using $100 \mathrm{~g} / \mathrm{L}$ feeding date juice glucose medium at two lower feeding rate values: 18 and $22 \mathrm{~mL} / \mathrm{h}$. The results are indicated in Figure 4.

In comparison with the results indicated in Figure $3 b$ $(100 \mathrm{~g} / \mathrm{L}$ and $33 \mathrm{~mL} / \mathrm{h})$, both assays showed that the final lactic acid concentration and productivity were higher at levels of $80.4 \mathrm{~g} / \mathrm{L} ; 84.9 \mathrm{~g} / \mathrm{L}$ and $1.15 \mathrm{~g} / \mathrm{L} . \mathrm{h} ; 1.21 \mathrm{~g} / \mathrm{L} . \mathrm{h}$, respectively (Figure $4 \mathrm{a}, \mathrm{b}$; Table 1). The residual glucose concentrations were approximately $1 \mathrm{~g} / \mathrm{L}$ lower, indicating higher glucose consumptions in both assays.

Figure 5 gathers the results performed at the different feeding rates $150,75,33, \mathrm{~mL} / \mathrm{h}$ at a glucose concentration of $62 \mathrm{~g} / \mathrm{L}$ (Figure $5 \mathrm{a}$ ) and at 33, 22 and $18 \mathrm{~mL} / \mathrm{h}$ at a glucose concentration of $100 \mathrm{~g} / \mathrm{L}$ (Figure 5b). This figure shows that the final lactic acid concentration, productivity and yield decrease with the feeding rate.

On comparing all the results of the batch and fedbatch assays gathered in Table 2, we can conclude that fed-batch process is here also a more efficient fermentation process for lactic acid production than batch culture process. The lactic acid production, productivity and lactic acid yield were then, respectively improved of $48.6 \%$, $56.6 \%$ and $20.5 \%$.

As shown in Figure 5, the lactic acid concentration and productivity levels decrease at higher feeding rates, 

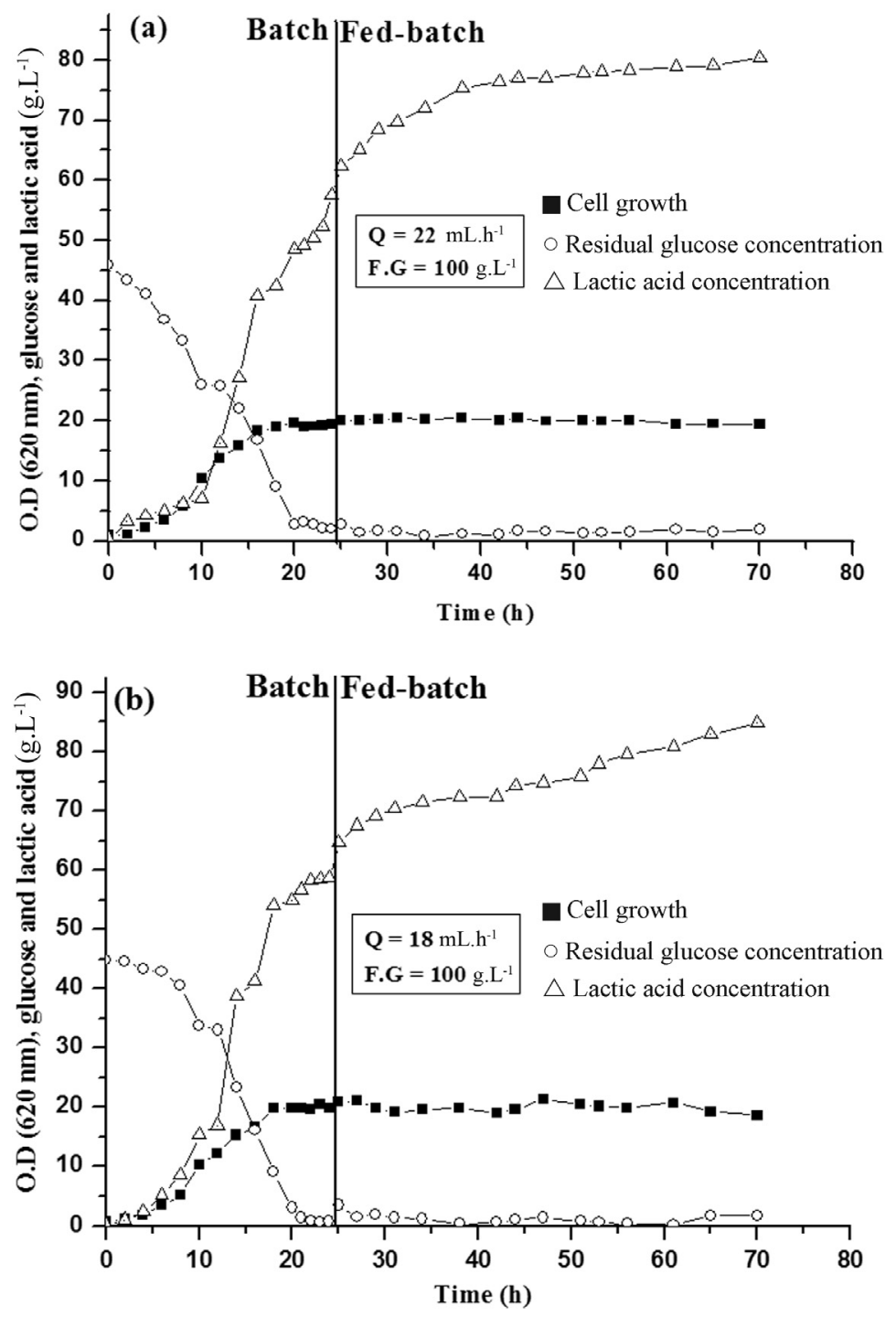

Figure 4 - $(a, b)$ - Effect of low feed rates on the cell growth, residual glucose and lactic acid production in fed-batch culture using date juice glucose as the feeding medium (100 g/l). Indices: Q: Feeding rate; F.G: Glucose concentration of the feeding solution.

which corroborates what has been observed by Roukas and Kotzekidou (1998) and Bai and al. (2003). However, if high performances are desired, specific care and control for substrate addition should be taken. In fact, as noted by Hofvendahl and Hagn-Hagerdal (2000), a high concentration of glucose can lead to high osmotic pressure for the cells, resulting in substrate inhibition.
Table 3 shows several reports regarding how lactic acid production works using fed-batch fermentations. Clearly, Lactobacillus lactis exhibited the highest productivity ( $2.2 \mathrm{~g} / \mathrm{L} . \mathrm{h})$ and lactic acid production $(210 \mathrm{~g} / \mathrm{L})$. The lactic acid production by $L$. casei using an exponential fed-batch culture with a glucose solution and yeast extract leads to similar results (Ding and Tan, 2006). In both of

Table 2 - Comparative performances between batch and fed-batch cultures for lactic acid production from date juice by L. casei subsp. rhamnosus.

\begin{tabular}{lcc}
\hline Kinetic parameters & Batch culture & Fed-batch culture $(\mathrm{Q}=33 \mathrm{~mL} / \mathrm{h}$ F.G. $=62 \mathrm{~g} / \mathrm{L})$ \\
\hline Lactic acid yield $(\mathrm{g} / \mathrm{g})$ & 1.41 & 1.7 \\
Productivity $(\mathrm{g} / \mathrm{L} \cdot \mathrm{h})$ & 0.83 & 1.3 \\
Lactic acid concentration $(\mathrm{g} / \mathrm{L})$ & 60.02 & 89.2 \\
\hline
\end{tabular}

Q: Feeding rate.

F.G: Glucose concentration of the feeding solution. 

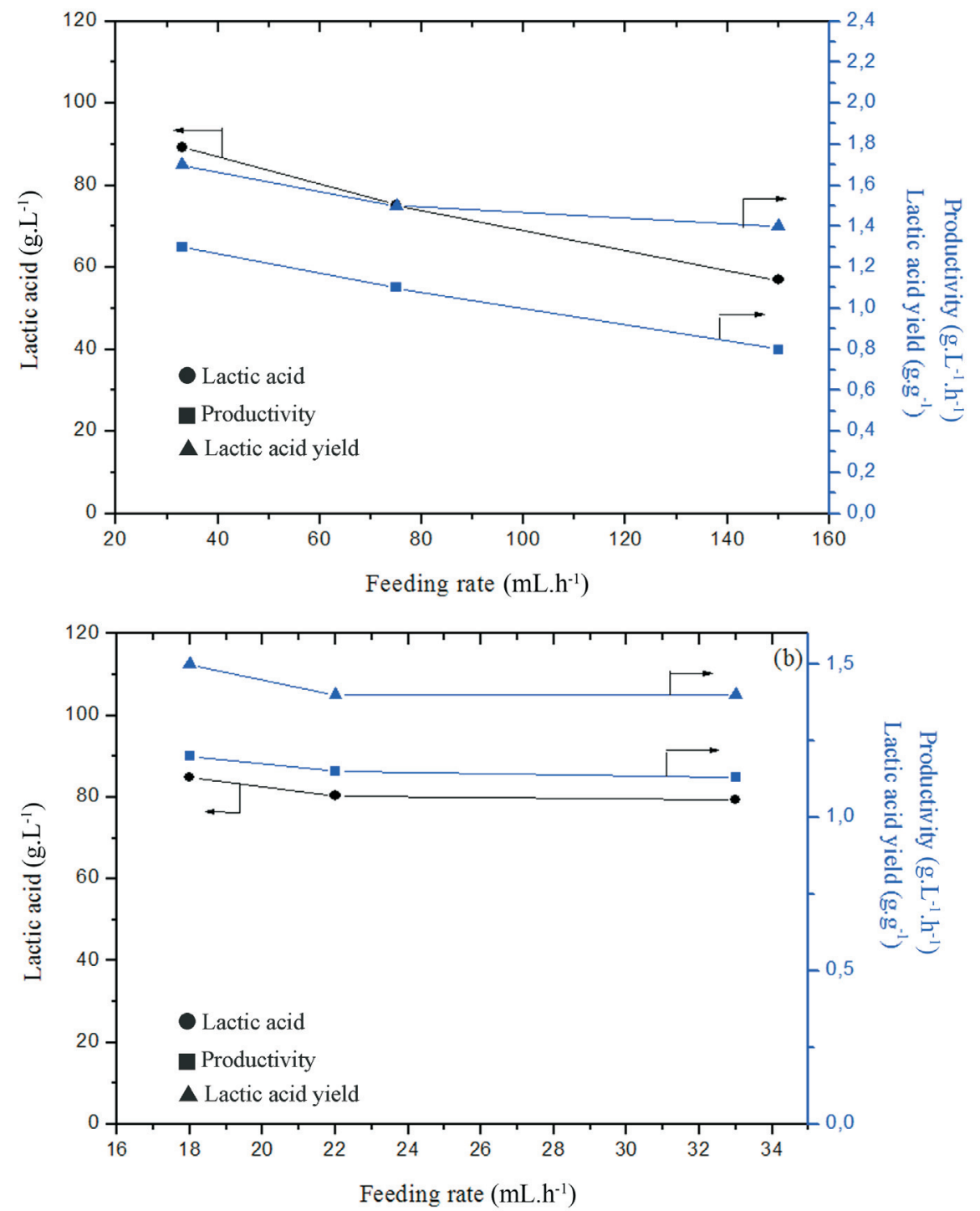

Figure 5 - (a, b) - Effect of the feeding rate on the kinetic parameters of date juice fermentation by L. casei subsp. rhamnosus in fed-batch culture. (a): Glucose concentration: $62 \mathrm{~g} / \mathrm{L}$. (b): Glucose concentration: $100 \mathrm{~g} / \mathrm{L}$.

Table 3 - Data reported on the lactic acid production from fed-batch fermentation.

\begin{tabular}{|c|c|c|c|c|}
\hline Microorganisms & Substrates & Lactic acid $\mathrm{g} / \mathrm{L}$ & Productivity g/L.h & References \\
\hline \multicolumn{5}{|l|}{ Mixed culture } \\
\hline (Lactobacillus casei and Lactococcus lactis) & Whey & 46.0 & 1.91 & Roukas and Kotzekidou, 1998 \\
\hline Lactobacillus lactis & Glucose & 210.0 & 2.20 & Bai et al., 2003 \\
\hline Rhizopus sp. MK-96-1196 & Glucose & 140.0 & 1.47 & Liu et al., 2005 \\
\hline Lactobacilus casei & Glucose & 210.0 & 2.14 & Ding and Tan, 2006 \\
\hline Lactobacillus amylophilus & potato starch & 43.7 & 0.75 & Yen and Kang, 2010 \\
\hline Immobilized Lactobacillus lactis & Glucose & 115.0 & 2.25 & Zhang et al., 2011 \\
\hline \multicolumn{5}{|l|}{ Mixed culture: } \\
\hline (Aspergillus niger and Lactobacillus sp.) & Artichoke & 120.5 & 3.34 & Ge et al., 2009 \\
\hline Immobilized Lactococcus lactis & Artichoke & 142 & - & Shi et al., 2012 \\
\hline Lactobacillus casei subsp. rhamnosus & Date juice & 89.2 & 1.30 & This work \\
\hline
\end{tabular}


these studies, a semi-synthetic medium was utilised. The choice of carbon source and fed-batch feeding strategies affects lactic acid production and appears to be a major control mechanism. The lactic acid production $(89.2 \mathrm{~g} / \mathrm{L})$ observed in this work appears to be much higher than the level obtained from deproteinised whey $(46 \mathrm{~g} / \mathrm{L})$ and starch (43.7 g/L) (Roukas and Kotzekidou, 1998; Yen and Kang, 2010).

\section{Conclusion}

In fed-batch lactic acid fermentation, the two principal variables influencing volumetric productivity and lactic acid yield are the feeding rate and the concentration of the feeding medium. This study shows that maintaining a low feeding rate and increasing the feeding medium concentration resulted in a higher lactic acid production. Maintaining a glucose concentration lower than $10 \mathrm{~g} / \mathrm{L}$ throughout the culture minimises substrate inhibition.

The results concluded from this study suggest that the fed-batch culture could significantly improve lactic acid production, and the proposed strategy was simple and easy to implement.

\section{Acknowledgments}

This work was supported by the accord-programme $\mathrm{N}^{\circ}$ COMDU 502 of Comité Mixte d'Evaluation et de Prospective (CMEP) between Algeria and France.

\section{References}

Abdel-Rahman MA, Tashiro Y, Sonomoto K (2013) Recent advances in lactic acid production by microbial fermentation processes. Biotechnol ADV 31:877-902.

Abou-Zeid AA, Abdelrhaman N, Baghlaf AO (1993) Use of date products in production of oxytetracycline by Streptomyces rimosus. Biosci Biotechnol Biochem 57:987-988.

Abou-Zeid AA, Bacshin NA, Baghlaf AO (1991) The formation of oxytetracycline in date-coat medium. Bioresour Technol 37:179-184.

Bai DM, Wei Q, Yan ZH et al. (2003) Fed-batch fermentation of Lactobacillus lactis for hyper-production of L-lactic acid. Biotechnol Lett 25:1833-1835.

Ben Salah R, Jaouadi B, Bouaziz A et al. (2011) Fermentation of date palm juice by curdlan gum production from Rhizobium radiobacter ATCC $6466^{\mathrm{TM}}$ : Purification, rheological and physico-chemical Characterization. LWT-Food Sci Technol 44:1026-1034.

Ding S, Tan T (2006) L-Lactic acid production by Lactobacillus casei fermentation using different fed-batch feeding strategies. Process Biochem 41:1451-1454.

El-Juhany LI (2010) Degradation of Date Palm Trees and Date Production in Arab Countries: Causes and Potential Rehabilitation. Aust J basic Appl Sci 4:3998-4010.

Gao C, Ma C, Xu P (2011) Biotechnological routes based on lactic acid production from biomass. Biotechnol Adv 29:930-939.

Ge XY, Qian H, Zhang WG (2009) Improvement of L-lactic acid production from Jerusalem artichoke tubers by mixed cul- ture of Aspergillus niger and Lactobacillus sp. Bioresour Technol 100:1872-1874.

Hujanen M, Linkos S, Linko YY et al. (2001) Optimisation of media and cultivation conditions for $\mathrm{L}(+)$-lactic acid production by Lactobacillus casei NRRL B-441. Appl Microbiol Biotechnol 56:126-130.

Hofvendahl K, Hahn-Hägerdal B (2000) Factors affecting the fermentative lactic acid production from renewable resources. Enzyme Microb Technol 26:87-107.

Kunji ERS, Mierau I, Hagting A, Poolman B, Konings WN (1996) The proteolytic systems of lactic acid bacteria. Antonie van Leeuwenhoek 70:187-221.

Lee J, Lee SY, Park S et al. (1999) Control of fed-batch fermentations. Biotechnol Adv 17:29-48.

Liu T, Miura S, Arimura T et al. (2005) Evaluation of lactic acid production in batch, fed batch, and continuous cultures of Rhizopus sp. MK-96-1196 using an airlift bioreactor. Biotechnol Bioprocess Eng 10:522-527.

Luna-Flores $\mathrm{CH}$, Ramírez-Cordova JJ, Pelayo-Ortiz $\mathrm{C}$ et al. (2010) Batch and fed-batch modeling of carotenoids production by Xanthophyllomyces dendrorhous using Yucca fillifera date juice as substrate. Biochem Eng J 53:131-136.

Mehaia MM (1991) Fermentation of date extracts to ethanol and vinegar in batch and continuous membrane reactors. Enzyme Microb Technol 13:257-261.

Nancib A, Nancib N, Boudrant J (2009) Production of lactic acid from date juice extract with free cells of single and mixed cultures of Lactobacillus casei and Lactococcus lactis. World J Microbiol Biotechnol 25:1423-1429.

Nancib N, Nancib A, Boudrant J (1997) Use of waste products in the fermentative formation of baker's yeast biomass by Saccharomyces cerevisiae. Bioresour Technol 60:67-71.

Nancib N, Ghoul M, Larous L et al. (1999) Use of date products in production of the thermophilic dairy strain Streptococcus thermophilus. Bioresour Technol 67:291-295.

Oh H, Wee YJ, Yun JS et al. (2005) Lactic acid production from agricultural resources as cheap raw materials. Bioresour Technol 96:1492-1498.

Qureshi N, Blaschek HP (2001) Recent advances in ABE fermentation: hyperbutanol producing Clostridium beijerinckii BA101. J Ind Microbiol Biotechnol. 27:287-291.

Roukas T, Kotzekidou P (1998) Lactic acid production from deproteinized whey by mixed cultures of free and coimmobilized Lactobacillus casei and Lactococcus lactis cells using fedbatch culture. Enzyme Microb Technol 22:199204.

Serrazanetti DI, Sado-Kamdem SL, Corsetti A et al. (2011) Acid Stress-Mediated Metabolic Shift in Lactobacillus sanfranciscensis LSCE1. Appl Environ Microbiol 77:2656-2666.

Shi Z, Wei P, Zhu X et al. (2012) Efficient production of 1-lactic acid from hydrolysate of Jerusalem artichoke with immobilized cells of Lactococcus lactis in fibrous bed bioreactors. Enzyme Microbiol Technol 51:263-268.

Tavakkoli M, Hamidi-Esfahani Z, Azizi MH (2009) Optimization of Corynebacterium glutamicum Glutamic Acid Production by Response Surface Methodology. Food Bioprocess Technol DOI 10.1007/s11947-009-0242-7.

Van de Guchte M, Serror P, Chervaux C et al. (2002) Stress responses in lactic acid bacteria. Antonie Leeuwenhoek 82:187-216. 
Vasala A, Panula J, Neubauer P (2005) Efficient lactic acid production from high salt containing dairy by-products by Lactobacillus salivarius ssp. Salicinius with pretreatment by proteolytic microorganisms. J Biotechnol 117:421-431.

Wee YJ, Kim JN, Ryu HW (2006) Biotechnological production of lactic acid and its recent applications. Food Technol Biotech 44:163-172.

Yen HW, Kang JL (2010) Lactic acid production directly from starch in a starch-controlled fed-batch operation using
Lactobacillus amylophilus. Bioprocess Biosyst Eng 33:1017-1023.

Zhang Y, Cong W, Shi Y (2011) Repeated fed-batch lactic acid production in a packed bed-stirred fermentor system using a $\mathrm{pH}$ feedback feeding method. Bioprocess Biosyst Eng 34:67-73.

Associate Editor: Rosane Freitas Schwan

All the content of the journal, except where otherwise noted, is licensed under a Creative Commons License CC BY-NC. 